\title{
ANALISIS STRATEGI PENGEMBANGAN PRODUK USAHA SAMBELIN LAMPUNG DI KOTA BANDAR LAMPUNG
}

\author{
Soewito ${ }^{1}$ Sinta Yuliana ${ }^{2}$
}

Fakultas Ilmu Sosial dan Ilmu Politik, Universitas Bandar Lampung

Jl. Zainal Abidin Pagar Alam No.26, Labuhan Ratu, Kedaton, 35142, Bandar Lampung,

Indonesia

E-mail:

soewito@ubl.ac.id

sintayulianaa@gmail.com

Maraknya persaingan membuat perusahaan ingin memberikan keunggulan produk mereka, untuk itu perusahaan melakukan berbagai usaha agar dapat bertahan dalam menghadapi persaingan. Cara menghadapi persaing, perusahaan harus mempunyai strategi yang tepat sehingga dapat mengantisipasi dampak dari suatu kejadian serta mampu bertindak inovasi untuk mempertahankan dan meningkatkan kemampuan bersaing. Metode penelitiannya adalah Deskriptif. Sumber data yaitu data primer dan data sekunder. Metode pengumpulan data dengan cara kepustakaan dan penelitian lapangan menggunakan cara wawancara, observasi, dan dokumentasi. Data dianalisis menggunakan matriks IFE, EFE dan SWOT. Hasil penelitian menunjukkan kekuatan faktor internal yang mempengaruhi usaha Sambelin Lampung adalah keunggulan dalam hal rasa, keunggulan dalam hal penampilan, dan keunggulan dalam hal aroma. Kelemahan yang dimiliki oleh Sambelin Lampung kegiatan promosi yang belum meluas. Peluang adalah kosumen lebih menyukai makanan cepat saji. Sedangkan ancaman beredar produk sejenis dari pesaing.

Kata Kunci: SWOT, strategi 


\section{Pendahuluan}

Maraknya persaingan membuat perusahaan ingin memberikan keunggulan produk mereka, untuk itu perusahaan melakukan berbagai usaha agar dapat bertahan lama dalam menghadapi persaingan. Perusahaan mempersiapkan strategi untuk menghadapi persaing usaha, sehingga dapat meminimalisir dampak dari suatu kejadian dan mampu berinovasi untuk mempertahankan serta meningkatkan kemampuan bersaing. Membuat strategi bisnis bukanlah sesuatu pekerjaan yang gampang untuk pelaku bisnis dalam menghadapi para pesaing. Pelaku bisnis mampu membandingkan produk, harga, saluran distribusi serta promosinya dengan pesaing terdekat.

Ketatnya persaingan antar usaha seperti usaha kuliner mengharuskan perusahaan harus lebih bisa menggunakan peluang yang ada. Dalam menghadapi persaingan, perusahaan wajib merencanakan strategi yang tepat untuk mempertahankan perusahaan mereka. Kegiatan yang dirancang dalam menjalankan aktivitas kegiatan bisnis merupakan bagian terpenting untuk menjalankan usaha bisnis. Munculnya tantangan tersebut diperlukan suatu perencanaan bagi perusahaan sehingga konsumen dapat tertarik dengan perusahaan kita. Untuk menghadapi persaingan yang semakin ketat diperlukan strategi pengembangan usaha yang tepat.

Usaha dibidang kuliner tidak ada habisnya karena usaha kuliner selalu menjanjikan keuntungan yang besar. Dalam mengembangkan usaha kuliner pelaku bisnis wajib mempunyai ketekunan yang tinggi, pertimbangan utama dalam menekuni bisnis kuliner adalah cita rasa. Permintaan akan meningkat jika makanan sudah sesuai dengan selera konsumen. Usaha kuliner Sambelin adalah bisnis kuliner berbentuk sambal yang mempunyai rasa yang khas dan berbeda dari sambal-sambal lainya yang ada di nusantara. Bisnis kuliner Sambelin tidak hanya memiliki cita rasa yang khas tetapi kelebihan lainnya adalah aroma dari sambal itu sendiri yang membuat seseorang merasa tertarik saat mencium aromanya.

Berdasarkan penelitian ini adalah dengan tujuan penelitian untuk menentukan program strategi pengembangan usaha pada usaha Sambelin Lampung di Kota Bandar Lampung.

\section{Tinjauan Pusaka}

Menurut (David, 2003:15) melalui manajemen strategi keputusan organisasi dilakukan dengan membuat, menerapkan dan mengevaluasi untuk mencapai tujuan. Menurut (Learned et al., 1965) pada tahun 1960-an Analisis SWOT pertama kali ditemukan. SWOT digantikan dengan perencanaan berbasis sumber daya karena dipandang ketinggalan jaman pada beberapa tahun terakhir (Wener-felt, 1984;Grant,1991). Perencanaan bisnis merupakan proses disengaja, berurutan dan rasional. Kenyataan tidak demikian, perencanaan bisnis adalah aktivitas social yang dijelaskan sebagai sesuatu yang informal, irr dan no rasional (Taylor, 1982). Penggunaan kerangka kerja Dell Computer Corporation digunakan untuk membuat keputusan strategi untuk menerapkan kustomisasi massal, pembuatan just in time dan penjualan internet langsung (Collett, 1999). Menurut (Hunger dan Wheelen, 2006, p. 138) Kepanjangan dari SWOT yaitu, Strengths (kekuatan) dan Weaknesses (kelemahan) internal dari suatu instansi, serta Opportunities (peluang) dan Threats (ancaman) dalam lingkungan yang dihadapi suatu instansi. Analisis SWOT adalah penilaian menyeluruh terhadap strengths, weaknesses, opportunities, dan threats di suatu perusahaan. Untuk membuat beberapa strategi yang ada di perusahaan diperlukan Analisis SWOT seperti strategi promosi dan penempatan produk (Kotler \& Armstrong, 2008:64). Menurut (Jogiyanto 2005:46) Analisis SWOT menghasilkan strenght dan weaknesses dari sumber daya yang dimiliki perusahaan dan kesempatan eksternal serta tantangan yang dihadapi. Menurut 
(Jackson et al, 2003) Analisis SWOT adalah instrument perencanaan stategi klasik, instrument ini membantu perencana tentang sesuatu yang bisa diraih dan sesuatu yang harus mereka pertimbangkan. Menurut (Thompson et al, 2007.97) Perusahaan bisa mengukur kemampuan, kekurangan sumber daya organisasi, peluang pasar, dan ancaman eksternal terhadap masa yang akan datang menggunakan Analisis SWOT.

Dengan menggunakan analisis SWOT dapat menghasilkan beberapa strategi yang dapat diterapkan, yaitu SO Strategi (Strengths-Opportunities) yaitu menggunakan strengths internal perusahaan untuk memanfaatkan opportunities di luar perusahaan. ST Strategi (Strengths-Threats) yaitu menggunakan strenghts internal perusahaan untuk menghindari atau mengurangi dampak threats dari luar perusahaan. WO Strategi (WeaknessesOpportunities) yaitu mengatasi weaknesses internal perusahaan untuk memanfaatkan opportunities di luar perusahaan. WT Strategi (Weaknesses-Threats) yaitu mengurangi weaknesses internal perusahaan dan menghindari threats eksternal.

\section{Metode Penelitian}

Penelitian menggunakan metode Analisis Deskriptif yaitu, untuk mengidentifikasi lingkungan internal dan eksternal suatu perusahaan, objek penelitian Sambelin Lampung. Metode analisis datanya ialah metode kualitatif yaitu, untuk menguraikan secara deskriptif karakteristik responden dan perkembangan program yang dijalankan Sambelin Lampung.

Teknik pengumpulan data penelitian yaitu mengumpulkan data informasi melalui pengamatan secara langsung ketempat obyek penelitian dengan cara:

- Observasi adalah pengamatan yang dilakukan peneliti untuk mengetahui secara langsung lokasi tempat penelitian.

- Wawancara dilakukan untuk mengumpulkan data dengan mengajukan pertanyaan kepada seorang narasumber.

- Dokumentasi adalah mengumpulkan data dengan cara menganalisis dokumen yang dibuat.

Dokumen ialah data yang tersimpan dalam bentuk dokumentasi.

Penelitian dilakukan di tempat pembuatan Sambelin Lampung yaitu beralamat di Perumahan Glora Persada Blok I No 15, Raja Basa, Raja Basa Raya , Kota Bandar Lampung.

Teknik analisis data yaitu Analisis SWOT. Analisis SWOT adalah mengidentifikasi berberapa faktor internal dan eksternal untuk membuat strategi perusahaan. Analisis ini untuk memaksimalkan strengths dan opportunities, serta meminimalkan weaknesses dan threats. Perencanaan strategi harus menganalisis berbagai faktor strategi perusahaan (strengths, Weaknesses, Opportunities, Threats) dalam kondisi saat ini.

Alat untuk faktor-faktor strategi perusahaan yaitu matriks SWOT yaitu, menggambarkan bagaimana Opportunities dan Threats eksternal yang dihadapi perusahaan untuk bisa disesuaikan dengan Strengths dan Weaknesses yang dimiliki. Matriks SWOT menghasilkan alternatif strategi. Sebelum membuat matriks faktor strategi internal dan eksternal, kita harus mengetahui Internal Factors Analysis Summary (IFAS) dan Ekternal Factors Analysis Summary (EFAS) terlebih dahulu.

\section{Hasil Dan Pembahasan}

Dalam menggunakan analisis SWOT dibutuhkan wawancara. Wawancara ini bertujuan untuk meminta keterangan kepada narasumber mengenai Sambelin Lampung. Berikut daftar narasumber yang ingin di wawancara: 
Tabel 1. Informasi Penelitian

\begin{tabular}{|l|l|l|l|l|}
\hline No & \multicolumn{1}{|c|}{ Nama } & Usia & Jenis Kelamin & Pekerjaan \\
\hline 1. & SY & 21 & Perempuan & Mahasiswa \\
\hline 2. & IY & 25 & Perempuan & Karyawan \\
\hline 3. & WN & 20 & Laki-laki & Mahasiswa \\
\hline 4. & ES & 30 & Perempuan & Karyawan \\
\hline 5. & TH & 21 & Laki-laki & Mahasiswa \\
\hline
\end{tabular}

Sumber: Hasil wawancara peneliti di Sambelin Lampung

Keterangan tabel di atas:

1. Peneliti menetapkan sebanyak 5 orang sebagai informan. Dalam proses wawancara informan merupakan pelanggan yang sudah lebih dari dua kali membeli produk Sambelin Lampung.

2. Informan berusia 20 - 30 tahun yaitu pelanggan Sambelin Lampung.

Dari hasil wawancara responden yang telah diolah oleh peneliti maka disimpulkan sebagai berikut:

Tabel 2. Identifikasi Sambelin Lampung

\begin{tabular}{|c|c|c|}
\hline Faktor internal & Kekuatan & Kelemahan \\
\hline Kualitas & Mempunyai ciri khas tersendiri & - \\
\hline $\begin{array}{l}\text { Pemasaran } \\
\text { 1. Product }\end{array}$ & Mempunyai ciri khas & - \\
\hline 2. Price & Adanya sistem Reaward & - \\
\hline 3. $\quad$ Place & Pelayanan cepat dan ramah & $\begin{array}{ll}\text { Tempat } & \text { kurang } \\
\text { Strategis } & \end{array}$ \\
\hline 4. Promotion & Wilayah promosi cukup luas & $\begin{array}{l}\text { Belum memanfaatkan } \\
\text { promosi online dengan } \\
\text { baik }\end{array}$ \\
\hline Produksi/operasi & Layanan gratis ongkir & - \\
\hline $\begin{array}{l}\text { Penelitian dan } \\
\text { Pengembangan }\end{array}$ & $\begin{array}{l}\text { Mengembangkan inovasi produk dengan cara } \\
\text { memperbanyak menu }\end{array}$ & - \\
\hline Faktor eksternal & Peluang & Ancaman \\
\hline Kekuatan Ekonomi & - & $\begin{array}{l}\text { Kenaikan bahan baku } \\
\text { mempengaruhi } \\
\text { Produksi }\end{array}$ \\
\hline $\begin{array}{lr}\text { Kekuatan } & \text { Sosial, } \\
\text { Budaya, } & \text { Demografis, } \\
\text { Lingkungan } & \\
\end{array}$ & $\begin{array}{l}\text { Memanfaatkan budaya masyarakat yang } \\
\text { senang makanan cepat saji }\end{array}$ & Pandemi Covid 19 \\
\hline Kekuatan Teknologi & $\begin{array}{l}\text { Memanfaatkan media sosial sebagai media } \\
\text { promosi }\end{array}$ & - \\
\hline
\end{tabular}

Sumber: Data Primer yang diolah oleh peneliti (2020)

Matriks Internal Factor Evaluation (IFE) untuk mengetahui beberapa faktor internal berkaitan dengan Strengths dan Weaknesses perusahaan yang termasuk penting. Berdasarkan hasil identifikasi berikut hasil Matriks IFE Sambelin Lampung: 
Tabel 3. Matriks IFE Kekuatan Sambelin Lampung

\begin{tabular}{|l|l|l|l|l|}
\hline Key internal Factors & Bobot & Rating & Skor & Program Kerja \\
\hline $\begin{array}{l}\text { Kualitas produk mempunyai ciri } \\
\text { khas }\end{array}$ & 0.20 & 4 & 0.80 & Mempertahankan kualitas produk \\
\hline Ada sistem reward & 0.10 & 2 & 0.20 & $\begin{array}{l}\text { Menambahkan variasi reward } \\
\text { bagi pelanggan setia }\end{array}$ \\
\hline Pelayanan cepat dan ramah & 0.20 & 3 & 0.60 & $\begin{array}{l}\text { Tetap mempertahankan kualitas } \\
\text { pelayanan yang baik }\end{array}$ \\
\hline $\begin{array}{l}\text { Wilayah promosi yang cukup } \\
\text { luas }\end{array}$ & 0.10 & 3 & 0.30 & $\begin{array}{l}\text { Terus mengembangkan wilayah } \\
\text { promosi }\end{array}$ \\
\hline $\begin{array}{l}\text { Layanan gratis ongkir inovasi } \\
\text { Mengembangkan }\end{array}$ & 0.10 & 3 & 0.30 & $\begin{array}{l}\text { Tetap pertahankan layanan gratis } \\
\text { ongkir } \\
\text { produk }\end{array}$ \\
\cline { 2 - 4 } & $\mathbf{0 . 8 0}$ & Total & $\mathbf{2 . 5 0}$ & $\begin{array}{l}\text { Lebih mengembangkan inovasi } \\
\text { produk }\end{array}$ \\
\hline
\end{tabular}

Sumber: Data Primer yang diolah oleh peneliti (2020)

Keterangan hasil analisa Matriks IFE dari sisi strengths (kekuatan):

Semakin tinggi pengaruh suatu faktor terhadap perusahaan, semakin tinggi pula bobot yang di berikan. Bobot mengacu pada industri dimana perusahaan berada. Sedangkan rating di berikan dalam skala 1 - 4 (sangat lemah hingga sangat kuat) berdasarkan kondisi perusahaan.

1. Kekuatan utama Sambelin Lampung yaitu Kualitas produk mempunyai ciri khas 0.80 melalui bobot 0.20 (diatas rata-rata) dan rating 4. Kualitas produk sangat diutamakan didalam Usaha Sambelin Lampung karena kunci dari usaha kuliner yaitu Kualitas produk maka dari itu harus dipertahankan.

2. Kekuatan yang berikutnya yaitu Pelayanan/respon baik cepat tanggap dalam merespon calon konsumen. Skor 0.60 dengan bobot 0.20 (diatas rata-rata) dan rating 3. Pelayanan yang baik termasuk penting dalam suatu usaha karena pelayanan yang baik bisa membuat konsumen membeli kembali produk maka dari itu harus dipertahankan.

3. Kekuatan yang ke tiga adalah wilayah promosi yang cukup luas skor 0.30 melalui bobot 0.10 (rata-rata) rating 3. Wilayah promosi Sambelin Lampung cukup luas maka dari itu harus tetap di pertahankan.

4. Kekuatan yang ke empat adalah Layanan gratis ongkir skor 0.30 melalui bobot 0.10 (rata-rata) rating 3. Sambelin Lampung melayani gratis ongkir dengan minimal belanja 2 cup. Layanan gratis ongkir cukup membuat konsumen puas dan harus dipertahankan.

5. Kekuatan yang ke lima adalah mengembangkan inovasi produk skor 0.30 dengan bobot 0.10 (rata-rata) dengan rating 3. Sambelin Lampung perlu mengembangkan inovasi produk.

6. Kekuatan yang terakhir yaitu ada sistem reward skor 0.20 melalui bobot 0.10 (ratarata) rating 2. Sistem reward sebagai pemicu kedua dibidang usaha kuliner setelah kualitas produk maka dari itu harus dipertahankan. 
Tabel 4. Matriks IFE Kelemahan Sambelin Lampung

\begin{tabular}{|l|l|l|l|l|}
\hline Key internal factor & Bobot & Rating & Skor & Program kerja \\
\hline Lokasi yang kurang strategi & 0.10 & 2 & 0.20 & Mencari tempat yang lebih strategis \\
\hline \begin{tabular}{l} 
Belum $\begin{array}{c}\text { memanfaatkan } \\
\text { promosi online dengan baik }\end{array}$ \\
\cline { 2 - 5 }
\end{tabular} & 0.10 & 2 & 0.20 & $\begin{array}{l}\text { Memanfaatkan promosi secara online } \\
\text { dengan baik }\end{array}$ \\
\cline { 2 - 4 } & $\mathbf{0 . 2 0}$ & Total & $\mathbf{0 . 3 5}$ & \\
\hline Total & $\mathbf{1 . 0 0}$ & & $\mathbf{2 . 8 5}$ & \\
\hline
\end{tabular}

Sumber : Data primer yang telah diolah oleh peneliti (2020)

Keterangan hasil analisa Matriks IFE dari sisi weaknesses:

1. Kelemahan Sambelin Lampung yaitu tempat yang kurang strategis skor 0.20 melalui bobot 0.10 (rata-rata) dan rating 2. Sambelin Lampung kurang memperhatikan tempat dikarenakan mereka fokus pada penjualan online.

2. Kelemahan berikutnya ialah belum memanfaatkan promosi online dengan baik. Skor diberikan 0.20 dengan bobot 0.10 (rata-rata) rating 2. Sambelin Lampung perlu lebih aktif mempromosikan secara online melalui sosial media karena peran sosial media penting di kalangan masyarakat.

Matriks External Factor Evaluation (EFE) untuk mengevaluasi beberapa faktor eksternal perusahaan terdiri atas opportunities dan threats yang dihadapi suatu perusahaan. Faktor-faktor yang terdapat dalam Matriks EFE pada Sambelin Lampung ialah sebagai berikut:

Tabel 5. Matriks EFE Peluang Sambelin Lampung

\begin{tabular}{|l|l|l|l|l|l|}
\hline Key external factors & Bobot & Rating & Skor & Program Kerja & \\
\hline $\begin{array}{l}\text { Peluang } \\
\text { Memanfaatkan budaya masyarakat } \\
\text { yang menyukai makanan cepat saji }\end{array}$ & 0.30 & 4 & 1.2 & $\begin{array}{l}\text { Mengembangkan } \\
\text { produk dari Sambelin } \\
\text { Lampung }\end{array}$ \\
\hline $\begin{array}{l}\text { Media Sosial sebagai media } \\
\text { promosi }\end{array}$ & 0.30 & 4 & 1.2 & $\begin{array}{l}\text { Menggunakan media sosial } \\
\text { dan internet sebagai sarana } \\
\text { promosi }\end{array}$ \\
\cline { 2 - 6 } & $\mathbf{0 . 6 0}$ & Total & $\mathbf{2 . 4 0}$ & Sarian & \\
\hline
\end{tabular}

Sumber: Data Primer yang telah dioleh peneliti

Keterangan hasil Matriks EFE dari sisi Opportunities:

1. Peluang utama yaitu faktor Masyarakat lebih menyukai makanan cepat saji. Bobot 0.30 (tinggi dan kuat) dan rating 4 dengan skor 1.2. Hal ini menunjukan bahwa Masyarakat lebih menyukai makanan cepat saji itu berarti sebuah peluang untuk Sambelin Lampung.

2. Peluang berikutnya ialah Media Sosial sebagai media promosi dengan bobot 0.30 (tinggi/kuat) rating 4 dengan skor sebesar 1.2. Hal ini menunjukkan adanya peluang untuk Sambelin Lampung lebih memanfaatkan media sosial untuk media promosi mereka untuk meningkatkan penjualan. 
Tabel 6. Matriks EFE Ancaman Sambelin Lampung

\begin{tabular}{|l|l|l|l|l|}
\hline Key external factors & Bobot & Rating & Skor & Program Kerja \\
\hline $\begin{array}{l}\text { Ancaman } \\
\text { Kenaikan Harga bahan baku }\end{array}$ & 0.20 & 3 & 0.60 & $\begin{array}{l}\text { Memproduksi produk sekali banyak } \\
\text { agar dapat mengurangi bahan baku }\end{array}$ \\
\hline $\begin{array}{l}\text { Pandemi Covid 19 membuat } \\
\text { ekonomi masyarakat tidak } \\
\text { stabil }\end{array}$ & 0.20 & 2 & 0.40 & $\begin{array}{l}\text { Mengadakan promo agar konsumen } \\
\text { dapat membeli produk }\end{array}$ \\
\cline { 2 - 4 } & $\mathbf{0 . 4 0}$ & Total & $\mathbf{1 . 0 0}$ & \\
\hline Total & $\mathbf{1 . 0}$ & & $\mathbf{3 . 4 0}$ & \\
\hline
\end{tabular}

Sumber: Data primer yang telah diolah oleh peneliti (2020)

Keterangan hasil analisis Matriks EFE dari sisi Threats (ancaman) yaitu :

1. Ancaman dengan skor tertinggi 0.60 yaitu Kenaikan Harga bahan baku bobot 0.20 (diatas rata-rata) rating 3. Oleh karena itu Sambelin Lampung perlu meningkatkan survei tempat beli bahan baku.

2. Ancaman berikutnya ialah Pandemi Covid 19 membuat ekonomi masyarakat tidak stabil dengan skor 0.40 bobot 0.20 (rata-rata) rating 2. Pandemi Covid saat ini membuat ekonomi masyarakat tidak stabil maka daari itu Sambelin perlu mengadakan Promo harga karena dengan mengadakan promo dapat menarik daya beli masyarakat.

Matriks SWOT untuk membantu perusahaan dalam mengembangkan empat tipe strategi yaitu, strategi SO, WO, ST, dan WT. Berikut adalah strategi yang dapat dimanfaatkan oleh Sambelin Lampung:

Tabel 7. Matriks SWOT Sambelin Lampung

\begin{tabular}{|c|c|c|}
\hline EFE & $\begin{array}{l}\text { Strengths } \\
\text { 1. Kualitas produk mempunyai ciri } \\
\text { khas } \\
\text { 2. Ada sistem reward } \\
\text { 3. Pelayanan/respon baik cepat dan } \\
\text { ramah } \\
\text { 4. Wilayah promosi cukup luas } \\
\text { 5. Layanan gratis ongkir } \\
\text { 6. Mengembangkan inovasi produk }\end{array}$ & 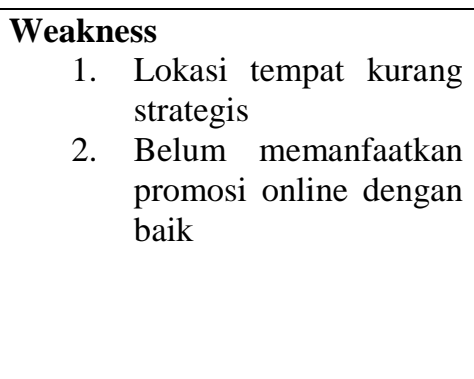 \\
\hline $\begin{array}{l}\text { Opportunities } \\
\text { 1. Memanfaatkan masyarakat } \\
\text { yang menyukai makanan } \\
\text { cepat saji. } \\
\text { 2. Media Sosial sebagai media } \\
\text { promosi. }\end{array}$ & $\begin{array}{cl}\text { Strategi SO } \\
\text { 1. } & \text { Strategi pelayanan/respon } \\
\text { 2. } & \text { Strategi Promosi } \\
\text { 3. } & \text { Strategi pengembangan produk }\end{array}$ & $\begin{array}{cl}\text { Strategi WO } \\
\text { 1. } & \text { Strategi inovasi produk } \\
\text { 2. } & \text { Strategi lokasi usaha } \\
\text { 3. } & \text { Strategi promosi }\end{array}$ \\
\hline $\begin{array}{l}\text { Threats } \\
\text { 1. Kenaikan Harga bahan } \\
\text { baku. } \\
\text { 2. Pandemi Covid-19 membuat } \\
\text { ekonomi masyarakat tidak } \\
\text { stabil. }\end{array}$ & $\begin{array}{l}\text { Strategi ST } \\
\text { 1. } \begin{array}{l}\text { Strategi pengembangan produk dan } \\
\text { meningkatkan kualitas produk }\end{array}\end{array}$ & $\begin{array}{l}\text { Strategi WT } \\
\text { 1. } \\
\text { Strategi } \\
\text { mengoptimalkan } \\
\text { proses pembuatan } \\
\text { bahan baku yang telah } \\
\text { tersedia }\end{array}$ \\
\hline
\end{tabular}

Sumber : Data primer yang telah diolah oleh peneliti (2020) 
Kesimpulan Strategi Strength-Opportunity (SO), berdasarkan kekuatan (Strength) dan peluang (Opportunity) yang di miliki Sambelin Lampung, maka terdapat 3 Strategi yang dapet di terapkan yaitu :

1. Strategi pelayanan/respon

Sambelin Lampung sudah mempunyai pelanggan tetap. Untuk itu sebaiknya dilakukan strategi pelayanan/respon. Hal ini bertujuan agar konsumen nyaman karena pelayanan/respon sambelin lampung cepat tanggap membuat konsumen senang karena mereka merasa dihargai.

2. Strategi promosi

Sambelin Lampung termasuk usaha kuliner yang dijual secara online. Promosi sangatlah penting untuk kemajuan usaha Sambelin Lampung karena untuk meningkatkan penjualan pemilik usaha harus memperkenalkan usaha mereka dengan cara mempromosikan. Sambelin Lampung sangat memanfaatkan media sosial untuk strategi promosi mereka.

3. Strategi pengembangan produk

Ditengah persaingan yang semakin ketat, Sambelin Lampung perlu mempersiapkan program pengembangan produk. Untuk itu Sambelin Lampung perlu menerapkan strategi pengembangan produk agar dapat mencapai peluang.

Strategi Weaknees-Opportunity (WO), peluang yang di miliki Sambelin Lampung dapat mengurangi kelemahan dengan cara sebagai berikut:

1. Strategi inovasi produk

Sambelin Lampung memerlukan inovasi produk untuk menarik minat konsumen agar melakukan pembelian.

2. Strategi lokasi usaha

Untuk mengatasi kelemahan yang terletak pada lokasi usaha yang kurang strategis, Sambelin Lampung dapat melakukan strategi lokasi usaha dengan menemukan lokasi usaha yang baru dan strategis. Dengan begitu Sambelin Lampung memiliki potensi mendapatkan pelanggan baru.

3. Strategi promosi

strategi yang tepat untuk meningkatkan penjualan. Sambelin Lampung dapat memanfaatkan sosial media untuk media promosi.

Strategi Strength-Threat (ST) berdasarkan kekuatan (Strength) yang dimiliki Sambelin Lampung maka dapat menghindari ancaman (Threats) yang ada dengan strategi berikut ini :

1. Strategi pengembangan produk dan meningkatkan kualitas produk

Sambelin Lampung perlu mengembangkan produk untuk meningkatkan kualitas agar konsumen melakukan pembelian secara berulang.

Strategi Weakness-Threat (WT) Untuk mengurangi kelemahan (weakness) yang ada dan menghindari ancaman maka Sambelin Lampung sebaiknya menerapkan strategi berikut :

1. Strategi mengoptimalkan proses pembuatan dengan bahan baku yang telah tersedia Sambelin Lampung akan mengoptimalkan proses produksi dengan cara memanfaatkan bahan baku sebaik baiknya 


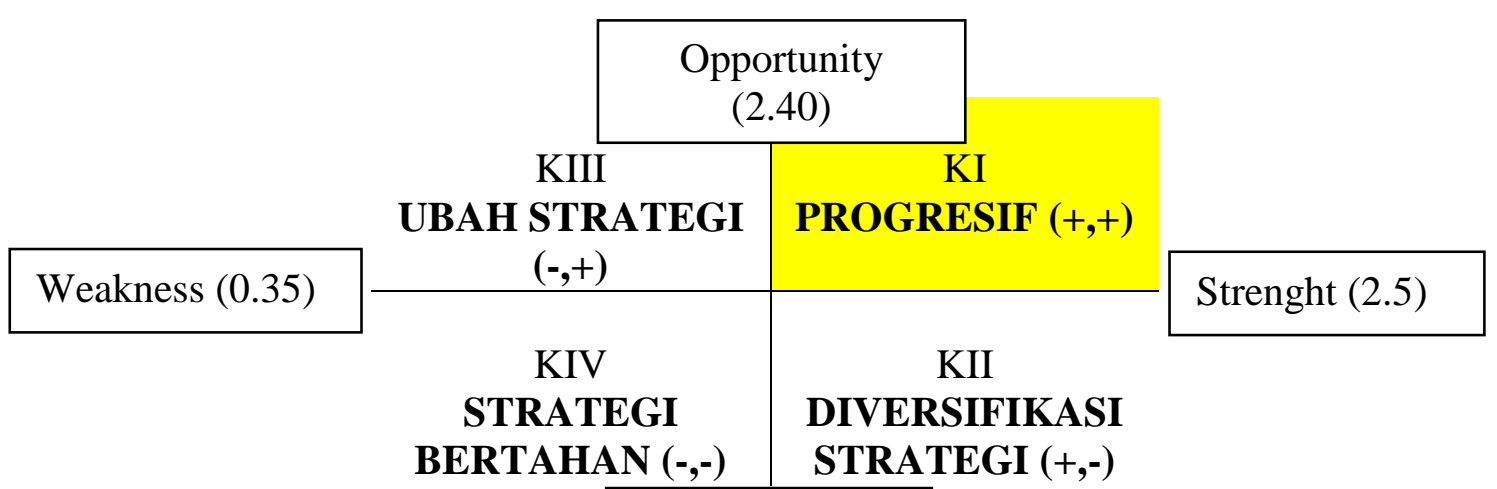

Threats (1.00)

Gambar 1. Diagram Cartecius

Berdasarkan gambar Diagram Cartecius diatas, menunjukkan Sambelin Lampung berada pada posisi yang tepat yaitu kuadran I yang berarti perusahaan tergolong perusahaan berkembang dikarenakan baru berdiri pada bulan juli 2020 dibanding dengan perusahaan lain yang sejenis. Walaupun masih tergolong perusahaan berkembang, Sambelin Lampung perlu mengamati opportunities (peluang) dan threats (ancaman) dari internal maupun eksternal. Dengan memperhatikan faktor-faktor yang ada untuk meningkatkan pemasaran dan penjualan Sambelin Lampung.

\section{5. kesimpulan dan saran}

\section{A. Kesimpulan}

Berdasarkan analisis internal dan eksternal perusahaan, strategi Sambelin Lampung adalah :

1. Dalam strategi pengembangan produk Sambelin Lampung diterapkan Matriks SWOT dengan menerapkan Strategi Promosi, Strategi Pelayanan dan Strategi Pengembangan Produk.

2. Strategi Promosi bisa dilakukan dengan memperluas wilayah promosi dengan cara memanfaatkan media sosial sebagai sarana promosi untuk menjangkau masyarakat lebih luas.

3. Strategi Pelayanan dapat dilakukan dengan cara cepat tanggap dalam merespon calon konsumen agar mereka nyaman dan ingin membeli produk itu kembali.

4. Strategi pengembangan produk dilakukan dengan cara mempersiapkan berbagai program usaha baru agar konsumen tidak bosan dan ingin melakukan pembelian secara berulang.

\section{B. Saran}

Berdasarkan penelitian yang sudah dilakukan mengenai Strategi Pengembangan Produk Sambelin Lampung, maka adapun saran yang ingin penulis sampaikan, yaitu:

a. Mempersiapkan program usaha baru untuk meningkatkan kualitas produk karena hal yang paling penting dalam mempertahankan usaha kuliner adalah kulitas produk

b. Lebih memanfaatkan sosial media untuk Strategi Promosi agar ruang lingkup usaha Sambelin Lampung lebih luas.

c. Untuk peneliti selanjutnya semoga penelitian ini bisa membantu mengetahui apakah strategi yang disarankan berpengaruh terhadap berkembangnya perusahaan. 